\title{
248 骨梁表面再構築シミュレーションのインプラント設計への応用
}

Application of Trabecular Surface Remodeling Simulation to Design of Implant

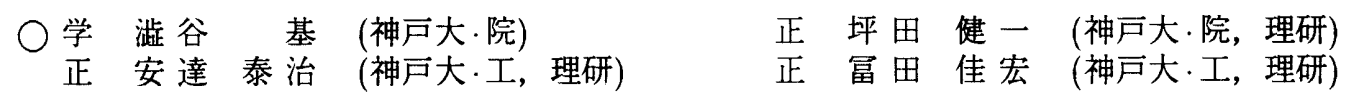

Motoi SHIBUTANI, Grad. Sch. Sci. \& Tech., Kobe Univ., Nada, Kobe, Japan

Ken-ichi TSUBOTA, Grad. Sch. Sci. \& Tech., Kobe Univ., Nada, Kobe, Japan, RIKEN

Taiji ADACHI,

Yoshihiro TOMITA,

Dept. Mech. Eng., Fac. Eng., Kobe Univ., Nada, Kobe, Japan, RIKEN

Dept. Mech. Eng., Fac. Eng., Kobe Univ., Nada, Kobe, Japan, RIKEN

Key Words : Biomechanics, Bone, Implant Design, Trabecular Surface Remodeling Simulation

\section{1.はじめに}

骨に装着する人工関節等のインプラントは，通常，実 験的な梌証に基づいて設計されており，その開発には多 大な費用と時間を要する。それらのコストを軽減し, 強 度および固定性に優れたより良いインプラントを設計す るためには，数値シミュレーションを援用した設計手法の 確立が重要となる ${ }^{(1)}$. 本報では, 骨梁表面再構筑シミュ レーション(2)を応用したインプラントの形状設計手法を 提案し，長骨に㨂入されたステムの形状設計を例に，そ の基本的な特性について検討する.

\section{2. 長骨ーステムモデル}

大腿骨への人工股関節ステムの挿入を想定し, Fig. 1(a) に示す長骨およびステムの単純 voxel モデルを作成した. voxel 要素の 1 辺の長さは $1.0 \mathrm{~mm}$ とし, シミュレーショ ン領域全体の要素分割数は, Fig. 1(a) に示寸 $X, Y, Z$ 方向をそれぞれ $30 ， 30 ， 150$ 要素とした. 外径 $30 \mathrm{~mm}$, 内径 $24 \mathrm{~mm}$, 長さ $140 \mathrm{~mm}$ の円筒状長骨に, 直径 24 $\mathrm{mm}$, 長さ $30 \mathrm{~mm}$ の円柱状ステムを, 全長の $2 / 3$ まで挿 入した。なお，以降は，長骨下端における境界条件の影 響の少ないモデル上部に着目した。骨部およびステム部 は，等方な線形弾性体と仮定し，ヤング率 $E$ およびポア ソン比レは, それぞれ骨部で $E_{b}=20 \mathrm{GPa}, \nu_{b}=0.30$, ステム部で $E_{s}=200 \mathrm{GPa}, \nu_{s}=0.29$ とした.

境界条件として, 長骨下端面は固着とし, ステム上端面 には, $Z$ 方向に $100 \mathrm{~N}$ の圧縮力 (Case Lc), および $X$ 方向 に $100 \mathrm{~N}$ のせん断力 (Case Ls) の二通りの荷重を加えた. それぞれの荷重条件における相当応力の分布を Fig. 1(b) に示す. Case Lc および Ls の両者において，相当応力は ステム中央下部で低く, 一方, 荷重が伝達されるステム 下端と長骨との接触部で高いことが分かる。

ステムの形状変化は，表面応力の一様化を目指す骨梁 表面再構築則 (2) を応用して行うものとし, 形成側閾値を $\Gamma_{u}=0.1$, 除去側閾値を $\Gamma_{l}=-1.0$, および感知半径 を $l_{L}=5.0 \mathrm{~mm}$ とした。 その際, 設計領域については, Fig. 1(b) の A - A' で示される長骨上端面の下側領域と し，さらに，設計領域に長骨を含む場合(Model 1)，およ び長骨を含まない場合(Model 2)の二通りを想定した。 な お, Model 2 では, 長骨要素から引張力を受けるステム 要素を除去することにより, 長骨とステムの間に引張力 が伝達されないと仮定した。

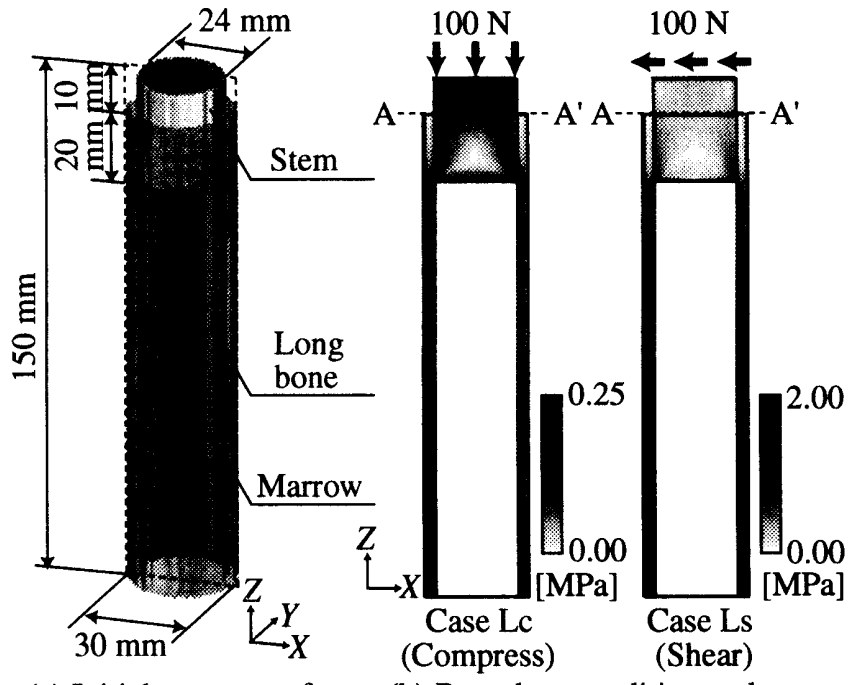

(a) Initial structure of long bone and stem

(b) Boundary condition and equivalent stress distribution

Fig. 1 Computational model of long bone and stem

\section{3. シミュレーション結果}

\section{1 ステムの形状変化と相当応力分布}

シミュレーションにより, 荷重条件に応じてステム要 素の形成・除去が繰り返されることで, 設計領域全体の ステム形状が変化した. 30th step における長骨およびス テムの形状とその相当応力分布を Fig. 2 に示す.

Model 1 では, Fig.1(a) に示すように, Case Lcおよ び Lsいずれの荷重条件においても，ステムは長骨と置換 して下方に伸び，ステム下方は空洞を抱える釣り鐘状の 形状となった：その際, Case Lcでは, 周方向にほほ均一 な形状となったのに対し, Case Lsでは, Fig.2(b) の○印 に示すように，荷重方向に厚くなる形状となった。また， 縦断面の相当応力分布に示されるように，Case Lc およ び Ls 共にステム中央下部で応力值が低くなった，特に， Case Ls では, ステム中央下部の応力が, 周囲と比較し て著しく低くなったために削られている。一方で，ステ ム先端部では応力値が高くなった。

Model 2 では, 設計領域上面から, Case Lc では全周 に渡って, Case Ls ではせん断方向へ 1 本だけ下方に伸 びたステム形状が得られた。これは，Model 2 では，骨 とステムの界面において引張力が伝達されないと仮定し たため, 荷重の方向に応じて, 圧縮力を伝える部位のみ 
にステム要素が形成されたためである，なお，Case Lcに おいて，4 方向に分かれた形状となったのは，要素分割 が粗いため, ボクセル分割の方向性の影響が現れた結果 である.また，縦断面の相当応力分布に示されるように， Case Lc および Ls 共に, 設計領域上面から, 長骨内面と の接触部にかけて，ステム部の応力值が高くなった。こ れは，ステム要素の除去量が形成量を上回ったことによ り，その形状が細くなったためである。

\section{2 長骨一ステム系の力学特性の変化}

長骨ーステム系の全ひずみエネルギの変化を Fig. 3 に 示す. Case Lc における全ひずみエネルギは, Fig. 3(a) に実線で示すように, Model 1 で単調隇少した.これは, 長骨がステムに次第に置換されることで，系全体の剛性 が単調に増加したためである. Model 2 では, 長骨およ びステムのひずみエネルギの変化が共に小さいため，同 図に破線で示すように，系全体としてはほとんど変化が 見られなかった。同様に, Case Ls における全ひずみ工 ネルギは, Fig. 3(b) に示すように, Case Lc とほぼ同様 の増加傾向を示した，なお，Model 1 における減少速度 の増加は，ステム中央下部が削られたことにより，ステ ム部のひずみエネルギが隇少したためである。

ステムに生じる最大相当応力の変化を Fig. 4 に示す. Case Lc における最大相当応力は, Fig. 4(a) に示すよう に, Model 1 では, 初期に減少した後, ほほ一定となっ た.これは，長骨がステムに置換される過程において，ス テムが長骨に沿って一様の厚さで下方へ伸びたためであ る. 一方, Model 2 では, 最大相当応力が変動しながら 徐々に増加した。この変動は, ステムと長骨の間に引張力 が伝達されないと仮定したことで生じるステム要素の除 去が, voxel 分割の粗さにより, 必ずしも連続的ではない ためである．要素分割を細かくすることにより，この変 動は小さくなるものと考えられる．また，増加の要因は， ステム形状が細くなり, 先端部の応力が増加したためで ある. Case Ls における最大相当応力は, Fig.4(b) に示 すように, Model 1 では, 初期の減少後, 単調増加した。 この単調増加は, ステムが下方へ伸びるにつれ, せん断 荷重による先端部のモーメントが増大し, 結果として先 端部に大きな応力が生じたためである. Model 2 につい ては, Case Lc とほほ同じ傾向を示した。

\section{4. おわりに}

長骨に挿入された人工股関節ステムを想定し，表面応 力の一様化の観点から, 表面再構築側を応用してステム の形状設計を試みた。 その結果, 荷重条件および設計領 域に応じて，それぞれ特徴的なステム形状が得られた。本 報で用いた手法は，ステムおよび長骨の局所的な力学状 態を考慮して，直接ステム形状を設計できることから，ス テムに限らず，他のインプラントの形状設計にも有用な 手法となり得る. 今後, 閾值および感知半径等のパラメー 夕の検討だけでなく，さらに実際的な制約の下で，実現 可能な設計指針について検討を加える必要がある。

本研究に対して一部, 文部省科学研究費補助金の援助 を受けたことを記し，謝意を表す。

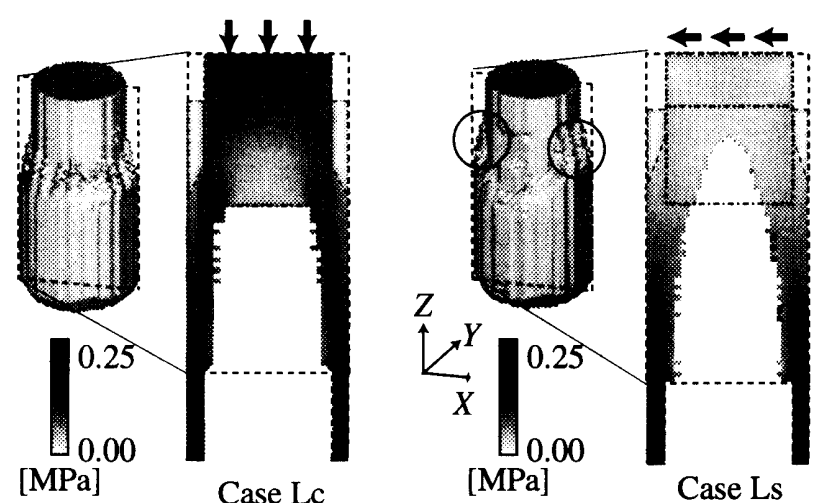

(a) Model 1
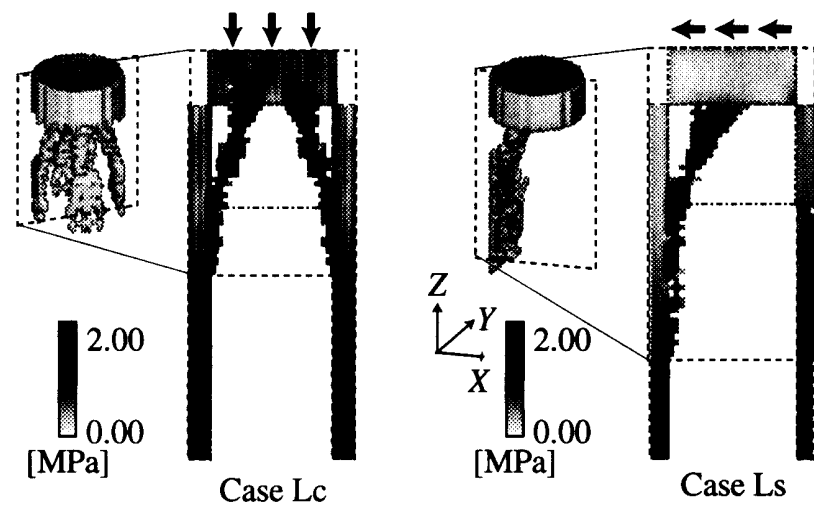

(b) Model 2

Case Ls

Fig. 2 Structual change and distribution of equivalent stress of long bone and stem at 30th step

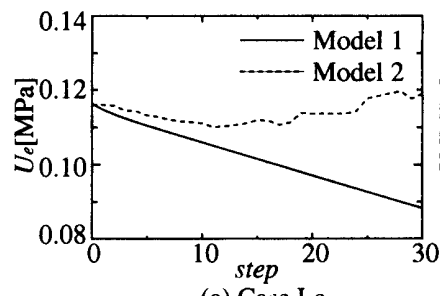

(a) Case Lc

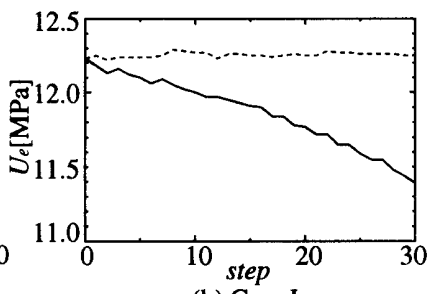

(b) Case Ls
Fig. 3 Change in total strain energy

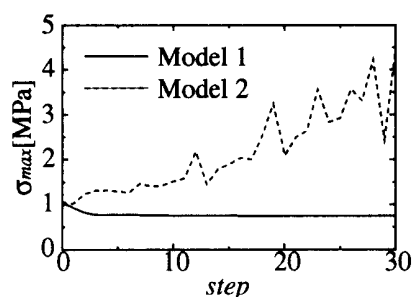

(a) Case Lc

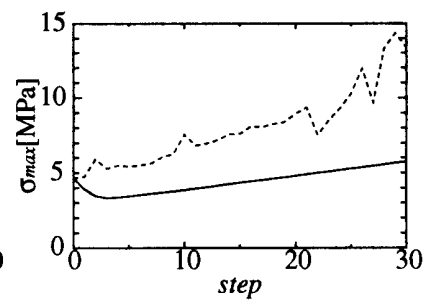

(b) Case Ls
Fig. 4 Change in maximum equivalent stress

\section{参考文献}

(1) Prendergast, P. J., Finite Element Models in Tissue Mechanics and Orthopaedic Implant Design, Clinical Biomech., 12-6 (1997), 343-366.

(2) 安達泰治·冨田佳宏 ·坂上拡 - 田中正夫, 応力の不均 一性による骨梁表面再構築モデルと形態変化シミュレー ション, 機論, 63C-607 (1997), 777-784. 